\title{
Correction to: Surgical Algorithms in Rhinoplasty: A Scoping Review of the Current Status
}

\author{
M. Mazhar Çelikoyar ${ }^{1}$ (I) Brandon Nickas $^{2} \cdot$ Eric Dobratz $^{3} \cdot$ Oguzhan Topsakal $^{2}$
}

Published online: 16 June 2021

(C) Springer Science+Business Media, LLC, part of Springer Nature and International Society of Aesthetic Plastic Surgery 2021

\section{Correction to: Aesth Plast Surg}

https://doi.org/10.1007/s00266-021-02337-w

This article was updated to incorporate belated author changes to remove affiliation 4, to correct Oguzhan Topsakal's name, to correct blinded information in the materials section, to correct Reference 6, and to update the number of articles that were excluded after full-text evaluation (16 in place of 21) in Fig. 1.

Publisher's Note Springer Nature remains neutral with regard to jurisdictional claims in published maps and institutional affiliations.

The original article can be found online at https://doi.org/10.1007/ s00266-021-02337-w.

M. Mazhar Çelikoyar

mazhar.celikoyar@gmail.com

1 Department of Otolaryngology, Istanbul Florence Nightingale Hospital, Abide-i Hürriyet Caddesi, No: 166, Şişli, Istanbul, Turkey

2 Department of Computer Sciences, Florida Polytechnic University, Lakeland, FL 33805, USA

3 Department of Otolaryngology, Eastern Virginia Medical School, Norfolk, VA 23507, USA 